\title{
Simple and Sensitive Method for Measurement of Metoclopramide in Cattle Plasma by LC-MS/MS Using a Multimode Chromatography
}

\author{
Kouko HAMAMOTO ${ }^{1)}$, Yasuharu MIZUNO ${ }^{1)}$, Masaki KATO ${ }^{2)}$, Norio YAMAGISHI ${ }^{3)}$ and Kazuhisa FURUHAMA ${ }^{2)}$ \\ 1)National Veterinary Assay Laboratory, Ministry of Agriculture, Forestry and Fisheries, 1-15-1 Tokura, Kokubunji, Tokyo 185-8511, Japan \\ ${ }^{2)}$ Department of Veterinary Basic Medicine, Faculty of Agriculture, Iwate University, 3-18-8 Ueda, Morioka, Iwate 020-8550, Japan \\ ${ }^{3)}$ Department of Veterinary Clinical Medicine, Faculty of Agriculture, Iwate University, 3-18-8 Ueda, Morioka, Iwate 020-8550, Japan
}

(Received 16 May 2012/Accepted 30 October 2012/Published online in J-STAGE 13 November 2012)

ABSTRACT. A quantitative assay method using LC/ESI-MS/MS for simultaneous determination of MCP in cattle plasma was developed and validated. Chromatographic separation was carried out using a multimode column $(2 \times 150 \mathrm{~mm}, 3 \mu \mathrm{m})$ with gradient elution $(0.05 \%$ formic $\mathrm{acid} / \mathrm{methanol}$ with $0.05 \%$ formic acid). $\mathrm{MCP}$ and levosulpiride (internal standard) were analyzed in the precursor/product ion pair of $\mathrm{m} / \mathrm{z}$ $300.1 / 226.9$ and 342.0/112.0, respectively. Linear calibration curves were obtained in the range of 2.5-500 $n \mathrm{~g} / \mathrm{ml}\left(\mathrm{R}^{2}>0.999\right)$ with a lower limit of quantification of $0.05 \mathrm{ng} / \mathrm{ml}$. Mean recoveries were $96-103 \%$, and the coefficient of variation was less than $6.5 \%$. Plasma MCP concentrations after intravenous administration at $0.4 \mathrm{mg} / \mathrm{kg}$ to 12 cattle were determined by the LC-MS/MS method. KEY WORDS: cattle, LC-MS/MS, metoclopramide, pharmacokinetics, plasma.

doi: 10.1292/jvms.12-0220; J. Vet. Med. Sci. 75(4): 509-513, 2013

Metoclopramide (MCP: 4 amino-5-chloro- $N-(2-$ (diethylamino)ethyl)-2-methoxy-benzamide, CAS:36462-5) is widely used as a gastrointestinal prokinetic agent for humans, cattle, swines, cats and dogs in Japan. MCP's action results from antagonism at dopamine- $2\left(\mathrm{D}_{2}\right)$ receptors [5] and serotonin $\left(5-\mathrm{HT}_{3}\right)$ receptors [7]. MCP also increases cholinergic receptor sensitivity to acetylcholine in the upper gastrointestinal (GI) tract [1]. MCP has efficacy in accelerated gastric emptying and reduced esophageal reflux. On the other hand, CNS side effects (shaking, muscle stiffness, etc.) have been reported in humans and goats after administration of MCP $[2,7,8]$, as this agent readily crosses the blood-brain barrier [6]. Although there is a large amount a pharmacokinetic data available in humans $[3,4,12-14,16]$, there is little data about the MCP concentration in serum and urine of cattle [9-11]. According to the pharmacokinetic study in Angus cows reported by Jones et al. [11], MCP was administered intravenously at a dose of $4 \mathrm{mg} / \mathrm{kg}$. In their study, the sensitivity of the HPLC-UV method adopted to determine plasma concentrations was $6 \mathrm{ng} / \mathrm{ml}$, and the plasma concentration of MCP could only be determined until $4 \mathrm{hr}$ after drug administration by this HPLC method. However, since the clinical recommended dose of MCP in Japan ranges from 0.1 to $0.4 \mathrm{mg} / \mathrm{kg}$, the sensitivity of the analytical method needed to be lower than $6 \mathrm{ng} / \mathrm{ml}$ in order to determine plasma MCP levels in cattle over two days after intravenous administration of $0.4 \mathrm{mg} / \mathrm{kg}$.

Analytical methods for the determination of MCP in blood

*Correspondence to: Hamamoto, K., National Veterinary Assay Laboratory, Ministry of Agriculture, Forestry and Fisheries, 1-15-1 Tokura, Kokubunji, Tokyo 185-8511, Japan.

e-mail: hamamok@nval.maff.go.jp

(C)2013 The Japanese Society of Veterinary Science samples include high performance liquid chromatography with a UV detector (HPLC-UV) [4, 8, 9, 11, 13, 14], GC-MS $[3,10,15]$ and LC-tandem mass spectroscopy (LC-MS/MS) $[12,16]$. Of these methods, the LC-MS/MS method has a highest detection sensitivity in human plasma, e.g., $0.78 \mathrm{ng} /$ $\mathrm{m} l$ (limit of quantitation: LOQ) according to Yan et al. [16]. However, no report is available on plasma MCP measurements in cattle by the LC-MS/MS method.

Here, a simple and sensitive analytical method utilizing LC-MS/MS was developed and validated to determine the MCP concentration in plasma in order to elucidate pharmacokinetics after an intravenous MCP administration at a clinical dose $(0.4 \mathrm{mg} / \mathrm{kg})$ to cattle.

Reagents and chemicals: MCP (100\% purity) and levosulpiride, used as the internal standard (IS), were purchased from Wako Pure Chemical Industries, Ltd. (Osaka, Japan) and Sigma-Aldrich (St. Louis, MO, U.S.A.), respectively. The LC/MS grade of formic acid (about 99\% purity) was purchased from Wako Pure Chemical Industries, Ltd. Other special grade reagents were also prepared.

Chromatographic conditions and instruments: The HPLC system consisted of a Nanospace SI-2/3202 degasser, a Nanospace SI-2//3201dual pump, a Nanospace SI-2/3133 autosampler and a Nanospace SI-2/3004 column oven (Shiseido Co., Ltd., Tokyo, Japan). Samples were maintained at $4^{\circ} \mathrm{C}$ in the autosampler. The Tandem mass spectrometer used was the TSQ Quantum Discovery Max made by Thermo Fisher Scientific Inc. (Waltham, MA, U.S.A.). The analytic column was the TSKgel VMpak-25 (particle size: $3 \mu \mathrm{m}, 2 \times$ 150 mm, Tosoh, Co., Ltd., Tokyo, Japan). The column temperature was $40^{\circ} \mathrm{C}$. The LC-MS/MS solvents were solvent A $(0.05 \%$ formic acid in water, v/v) and solvent B $(0.05 \%$ formic acid in methanol, v/v). The linear LC gradient for separation at a flow rate of $0.2 \mathrm{ml} / \mathrm{min}$ and the 14-min long LC gradient program included the following elution condi- 
tions: $10-40 \% \mathrm{~B}$ in $10 \mathrm{~min}, 40-10 \% \mathrm{~B}$ in $1 \mathrm{~min}$ and $10 \% \mathrm{~B}$ for $3 \mathrm{~min}$. The MS/MS conditions were as follows: positive mode of electrospray ionization (ESI), spray voltage of $3 \mathrm{kV}$, sheath gas pressure of 50 arbitrary units, aux gas pressure of 20 arbitrary units, capillary temperature of $300^{\circ} \mathrm{C}$, capillary offset of $35 \mathrm{~V}$, source CID of $-5 \mathrm{~V}$ and argon collision gas at 1.2 mTorr. Quantification was performed using selected reaction monitoring (SRM) of the transitions observed after fragmentation: $\mathrm{m} / \mathrm{z} 300.1\left[\mathrm{C}_{14} \mathrm{H}_{22} \mathrm{ClN}_{3} \mathrm{O}_{2}+\mathrm{H}\right]+\rightarrow 226.9$ $\left[\mathrm{C}_{10} \mathrm{H}_{12} \mathrm{ClN}_{2} \mathrm{O}_{2}\right]+$ (collision energy $(\mathrm{CE})=18 \mathrm{eV}$ ) for MCP and $\mathrm{m} / \mathrm{z} \quad 342.0 \quad\left[\mathrm{C}_{15} \mathrm{H}_{23} \mathrm{~N}_{3} \mathrm{O}_{4} \mathrm{~S}+\mathrm{H}\right]+\rightarrow 112.0 \quad\left[\mathrm{C}_{7} \mathrm{H}_{14} \mathrm{~N}\right]+$ $(\mathrm{CE}=26 \mathrm{eV})$ for IS.

Preparation of calibration standards and quality control samples: The stock solution of $\mathrm{MCP}(10 \mu \mathrm{g} / \mathrm{m} l)$ was prepared by diluting the first MCP solution with acetonitrile. The secondary standard solution $(1,000 \mathrm{ng} / \mathrm{ml})$ and the working standard solutions were produced by diluting the secondary standard solutions with mobile phase. Nine calibration standards of MCP (final concentrations: 0.05, 0.5, 2.5, 5, 10, $25,50,100$ and $500 \mathrm{ng} / \mathrm{m} l$ ) were prepared independently at every analytical time point. The stock solutions were stored at $-80^{\circ} \mathrm{C}$, and the secondary solution was stored at $-20^{\circ} \mathrm{C}$ until needed. The three quality control (QC) samples at concentrations of 5, 10 and $100 \mathrm{ng} / \mathrm{ml}$ were made by diluting the secondary solution with blank cattle plasma. The stock solution of IS $(0.1 \mathrm{mg} / \mathrm{m} l)$ was prepared using acetonitrile. The working IS solution $(100 \mathrm{ng} / \mathrm{m} l)$ was prepared by diluting the stock solution with acetonitrile and stored at $-20^{\circ} \mathrm{C}$.

Preparation of samples: Cattle plasma $(500 \mu l)$ was pipetted into a clean glass tube and the working IS solution $(100 \mu l)$ and acetonitrile $(1 \mathrm{~m} l)$ were added. The mixture was vortex-mixed for $30 \mathrm{sec}$. After centrifugation at 2,073 $\times g(3,000 \mathrm{rpm})$ for $10 \mathrm{~min}$, the supernatant was evaporated to dryness at $35^{\circ} \mathrm{C}$. The residue was reconstituted with the mobile phase $(500 \mu l)$. Each sample was filtered using a 0.45 $\mu \mathrm{m}$ membrane filter (Ekicrodisk 13, Nippon Genetics Co., Ltd., Tokyo, Japan). The sample solution $(4 \mu l)$ was injected into an LC-MS/MS system.

Validation of the method: The calibration curves of MCP were constructed from the peak area ratio of MCP/IS versus concentrations of MCP in the mobile phase. Linearity was determined using linear least-squares regression. The limit of detection (LOD) was defined as the plasma concentration that produced a signal-to-noise ratio $(\mathrm{S} / \mathrm{N})$ of 3 . The LOQ was defined as the lowest plasma concentration that produced an $\mathrm{S} / \mathrm{N}$ of 5 with a relative standard deviation (RSD) lower than $20 \%$ and accuracy between 80 and $120 \%$. The matrix effect of co-extracted components in cattle plasma on the ionization of MCP was evaluated by comparing the peak areas of MCP and IS spiked in pre-extracted blank plasma with those of a relevant standard in reconstitution solvent at an equivalent concentration.

Three QC samples, in which the concentrations of MCP were 2.5, 10 and $100 \mathrm{ng} / \mathrm{ml}$, were prepared to spike MCP in cattle blank plasma and measured by the same preparation method as plasma samples. The extraction recovery was estimated by comparing the peak area ratio of MCP to IS extracted from the QC samples $(n=6)$. Seven samples, in which the concentrations were $2.5,5,10,25,50,100$ and $500 \mathrm{ng} /$ $\mathrm{ml}$, were prepared to spike MCP in pre-extracted blank plasma. These samples were analyzed in each batch assay to determine intra-day and inter-day precision expressed as $\%$ RSD and accuracy (detected concentration/nominal concentration).

The stability of MCP in cattle plasma was tested using three QC samples $(n=6)$ by storing at -20 and $-80^{\circ} \mathrm{C}$ for 3 months. For stability of MCP in processed samples, the prepared QC samples $(n=6)$ were placed in an autosampler at $5^{\circ} \mathrm{C}$ for $24 \mathrm{hr}$ and then assayed for comparison.

Pharmacokinetic application: Twelve clinically healthy female Japanese Black cattle (0.9-5.2 years, 252-580 kg body weight) were used for MCP pharmacokinetics after intravenous administration of a $0.4 \mathrm{mg} / \mathrm{kg}$ dose of MCP, which is sold as a Primperan injection (Intervet K.K., Tokyo, Japan). The cattle were reared at the research farm of the Field Science Center, Iwate University (Morioka, Japan). Animals were maintained in a non-fasting state during this study. Venous blood samples $(10 \mathrm{ml})$ were obtained before and at $0.25,0.5,0.75,1,2,4,6,8,12,24$ and $30 \mathrm{hr}$ after MCP administration. The blood samples were immediately centrifuged, and the plasma samples were stored at $-80^{\circ} \mathrm{C}$ until analysis. The pharmacokinetic parameters of MCP in plasma were estimated using the WinNonlin computer program (ver. 3.1, SCI Software, Lexington, KY, U.S.A.). All experimental procedures were performed in accordance with the Guidelines for Animal Experimentation issued by the Japanese Association for Laboratory Animal Science (1987) or approved by the Animal Experimental Ethics Committee of Iwate University.

LC-MS/MS method: As MCP is a basic substance $(\mathrm{pKa}=9.71)[11]$, it was difficult to maintain in a reversedphase HPLC column for separation. Therefore, we applied a multimode column, which can be used for reversed-phase separation and ion-exchange separation. Using this column, we separated MCP with mobile phase containing $0.05 \%$ formic acid and analyzed the MCP plasma concentrations.

We selected a gradient of $0.05 \%$ formic acid solution and methanol with $0.05 \%$ formic acid for the HPLC mobile phase in our method, because the retention times of MCP and IS in the case of using gradient mode for mobile phase was very short for determination of MCP. Selection of the IS was based on the conditions of the LC-MS/MS method reported by Lee et al. [12]. The SRM monitor ions selected in this study for the determination of MCP and IS were similar to those of Lee et al. [12].

Figure 1 shows a representative LC-MS/MS chromatogram of standard (100 $\mathrm{ng} / \mathrm{ml}, \mathrm{A})$, blank plasma spiked with $\mathrm{MCP}$, the plasma $15 \mathrm{~min}$ following a single intravenous administration of MCP and blank plasma. No interaction peak was observed in blank plasma under the present assay conditions. The retention time was $7.6 \mathrm{~min}$ for MCP and 3.8 min for IS.

The linearity of the standard calibration curves $\left(\mathrm{R}^{2}\right)$ was $>0.999$ for MCP levels of $0.05-500 \mathrm{ng} / \mathrm{ml}$. The LOD and LOQ of our method were found to be 0.02 and $0.05 \mathrm{ng} / \mathrm{ml}$, and the signal-to-noise ratios of the LOD and LOQ were 3 

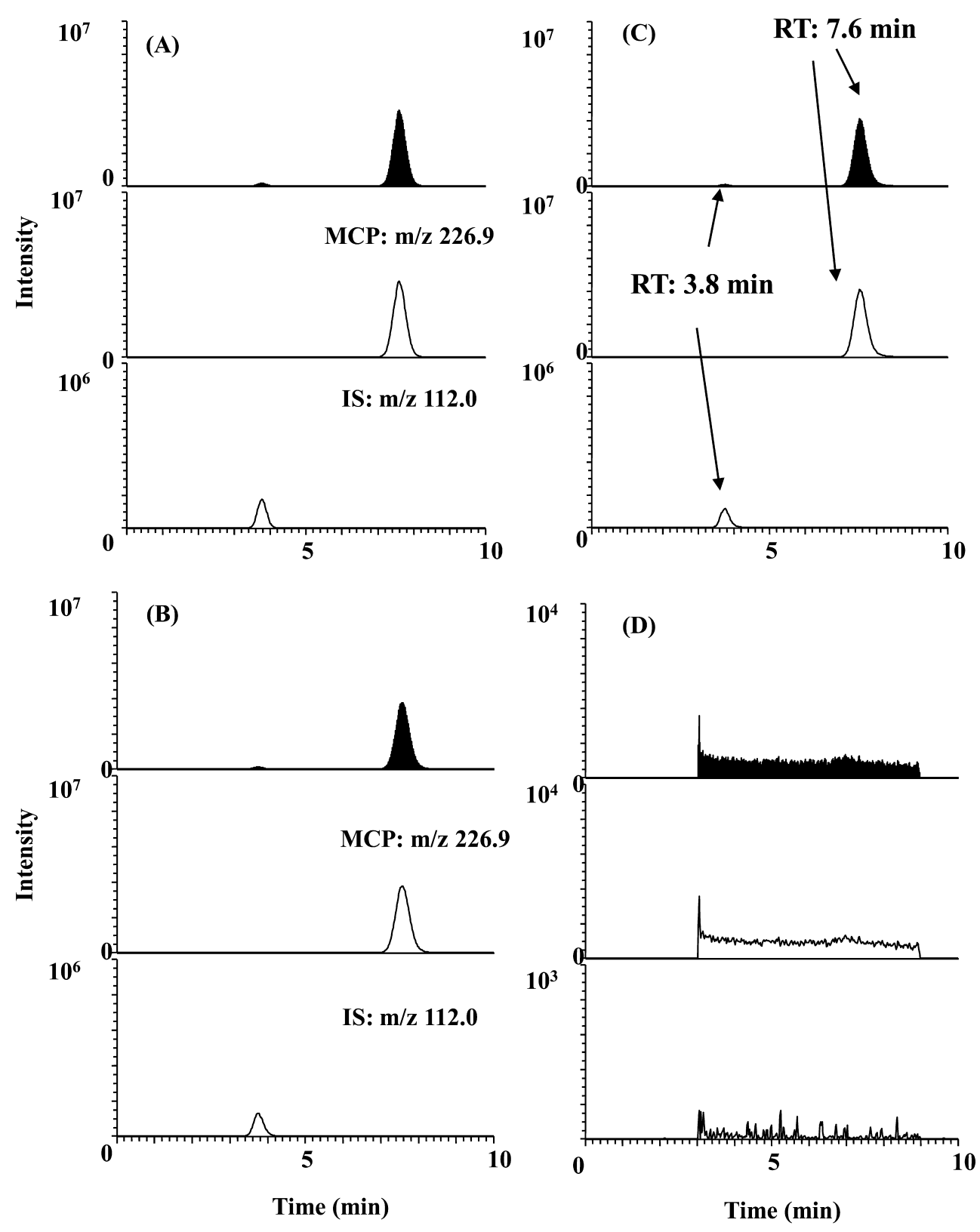

Fig. 1. Typical chromatograms of MCP and IS in cattle plasma. (A) standard (100 $\mathrm{ng} / \mathrm{m} l)$, (B) blank plasma spiked with MCP $(100 \mathrm{ng} / \mathrm{m} /)$, (C) the sample 15 min after i.v. administration at a dose of $0.4 \mathrm{mg} / \mathrm{kg}$, (D) blank plasma.

and 10, respectively. The LOD and LOQ were more sensitive than other previous reports using LC-MS/MS (LOQ: $0.78 \mathrm{ng} / \mathrm{ml}[16], 2 \mathrm{ng} / \mathrm{ml}[12])$.

Comparing the peak areas of MCP and IS spiked in preextracted blank plasma with those of relevant standards at equivalent concentrations, no significant increase or decrease (86-110\%) was noted for either MCP or IS, indicating that the matrix effects of the endogenous plasma component on the ionization of the two analytes were negligible.

The precision and accuracy data for intra-day and inter- day assays are shown in Table 1. This LC-MS/MS method possessed remarkable reproducibility with a precision of less than $6.5 \%$ and excellent accuracy ranging from $97.3 \%$ at 25 $n \mathrm{~g} / \mathrm{m} l$ to $110.0 \%$ at $500 \mathrm{ng} / \mathrm{ml}(\mathrm{n}=6)$. Extraction recoveries of MCP were found to be satisfactory, with the average value ranging from 96.0 to $103.4 \%$ at the three QC concentrations $(\mathrm{n}=6)$.

The stability study showed that the concentration of MCP was not significantly changed in plasma stored at either -20 or $-80^{\circ} \mathrm{C}$ for three months and in prepared plasma samples 
Table 1. Recovery, precision and accuracy of MCP in plasma by the LC-MS/MS assay method $(\mathrm{n}=6)$

\begin{tabular}{ccc}
\hline $\begin{array}{c}\text { Concentration in } \\
\text { control plasma } \\
(n \mathrm{~g} / \mathrm{m} l)\end{array}$ & $\begin{array}{c}\text { Mean } \\
\text { recovery } \\
(\%)\end{array}$ & $\begin{array}{c}\mathrm{CV} \\
(\%)\end{array}$ \\
\hline 2.5 & 97.1 & 3.4 \\
10 & 96.0 & 5.7 \\
100 & 103.4 & 1.3
\end{tabular}

\begin{tabular}{|c|c|c|c|c|}
\hline \multirow{2}{*}{$\begin{array}{l}\text { Concentration } \\
\text { in pre-extracted } \\
\text { control plasma } \\
(n \mathrm{~g} / \mathrm{m} l)\end{array}$} & \multicolumn{2}{|c|}{ Intra-day } & \multicolumn{2}{|c|}{ Inter-day } \\
\hline & $\begin{array}{l}\mathrm{CV} \\
(\%)\end{array}$ & $\begin{array}{c}\text { Accuracy } \\
(\%)\end{array}$ & $\begin{array}{l}\mathrm{CV} \\
(\%)\end{array}$ & $\begin{array}{c}\text { Accuracy } \\
(\%)\end{array}$ \\
\hline 2.5 & 3.9 & 100.0 & 6.0 & 98.8 \\
\hline 5 & 3.4 & 98.5 & 5.3 & 97.4 \\
\hline 10 & 2.9 & 98.3 & 6.5 & 98.4 \\
\hline 25 & 1.8 & 100.1 & 5.3 & 97.3 \\
\hline 50 & 2.5 & 90.1 & 4.8 & 98.7 \\
\hline 100 & 1.8 & 99.3 & 4.4 & 96.1 \\
\hline 500 & 0.3 & 109.1 & 0.4 & 110.0 \\
\hline
\end{tabular}

stored in an autosampler at $5^{\circ} \mathrm{C}$ for $24 \mathrm{hr}$. At a concentration of $2.5 \mathrm{ng} / \mathrm{ml}$, the average remaining values $(\mathrm{n}=5)$ in these three states were 92.6, 96.8 and $98.7 \%$. At a concentration of $10 \mathrm{ng} / \mathrm{m} l$, the average remaining values $(\mathrm{n}=5)$ were 97.8 , 98.0 and $98.1 \%$. At a concentration of $100 \mathrm{ng} / \mathrm{ml}$, the average remaining values $(n=5)$ were $98.3,103.6$ and $97.2 \%$. These results suggested that MCP had high stability under these three storage conditions.

Application: The present method was successfully applied to measure the plasma concentration of MCP up to $30 \mathrm{hr}$ after MCP administration to cattle. The mean plasma concentration-time curve is illustrated in Fig. 2, and its estimated pharmacokinetic parameters are shown in Table 2. The pharmacokinetic parameters were characterized with a three-compartment model. The apparent volume of distribution $(\mathrm{Vd})$ and the terminal half-life [half-life $\left(\mathrm{T}_{1 / 2}\right)$ of gamma phase] were $1.2 \pm 1.1 \mathrm{l} / \mathrm{kg}$ and $8.4 \pm 5.0 \mathrm{hr}$, respectively. The mean $\mathrm{T}_{1 / 2}$ beta $(1.3 \mathrm{hr})$ and mean $\mathrm{T}_{1 / 2}$ alpha $(0.3 \mathrm{hr})$ in our study were similar to the mean terminal half-life $\left(\mathrm{T}_{1 / 2}\right.$ beta: $0.9 \mathrm{hr}$ ) and the mean $\mathrm{T}_{1 / 2}$ alpha $(0.4 \mathrm{hr})$ reported by Jones et al. [11], which were estimated using a two-compartment model following intravenous administration to Angus cows at $4 \mathrm{mg} / \mathrm{kg}$. On the other hand, the Vd obtained in our study was within the range of the $\mathrm{Vd}$ results $(0.5 \pm 0.2 \mathrm{l} / \mathrm{kg}$ following intravenous administration to Angus steers at $8 \mathrm{mg} /$ $\mathrm{kg}$ and $2.1 \pm 0.8 \mathrm{l} / \mathrm{kg}$ following intravenous administration to Angus cows at $4 \mathrm{mg} / \mathrm{kg}$ ) reported by Jones et al. [11]. They also indicated that the plasma MCP concentration of Angus cows after intravenous administration $(4 \mathrm{mg} / \mathrm{kg})$ in their study became undetectable by the HPLC determination method (LOQ: $6 \mathrm{ng} / \mathrm{ml}$ ) after more than $4 \mathrm{hr}$ [11]. It is suggested that the difference between the results of Jones et al. [11] and those obtained by us may be caused by a difference in the dosage level, strain or length of the detectable period of MCP in the plasma used.

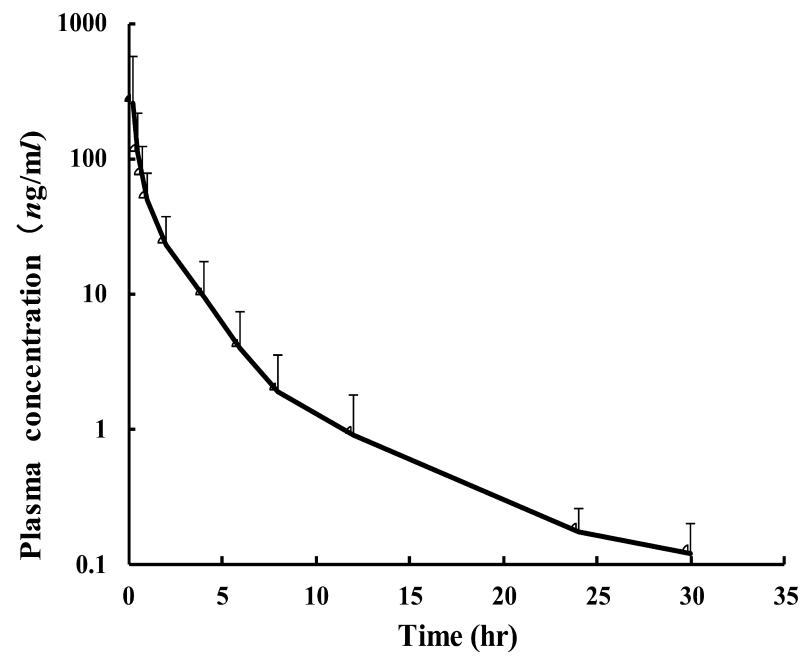

Fig. 2. Plasma concentration-time profile of MCP in cattle after i.v. administration at a dose of $0.4 \mathrm{mg} \mathrm{MCP} / \mathrm{kg}$ (mean $\pm \mathrm{SD}, \mathrm{n}=12$ ).

Table 2. Pharmacokinetic parameters of plasma MCP in cattle after intravenous administration at a dose of $0.4 \mathrm{mg} \mathrm{MCP} / \mathrm{kg}$ $($ mean $\pm \mathrm{SD}, \mathrm{n}=12)$

\begin{tabular}{|c|c|c|c|}
\hline PK parameter & Mean & SD & Unit \\
\hline A & 1170.12 & 1689.84 & $n \mathrm{~g} / \mathrm{m} l$ \\
\hline B & 107.08 & 168.54 & $n \mathrm{~g} / \mathrm{m} l$ \\
\hline $\mathrm{C}$ & 6.24 & 13.77 & $n \mathrm{~g} / \mathrm{m} l$ \\
\hline$\alpha$ & 5.54 & 4.05 & $\mathrm{hr}-1$ \\
\hline$\beta$ & 0.81 & 0.68 & $\mathrm{hr}-1$ \\
\hline$\gamma$ & 0.11 & 0.07 & $\mathrm{hr}-1$ \\
\hline Cmax ${ }^{a}$ & 1247.57 & 1707.47 & $n \mathrm{~g} / \mathrm{m} l$ \\
\hline $\mathrm{Vd}$ & 1.23 & 1.05 & $l / \mathrm{kg}$ \\
\hline $\mathrm{K}_{10}^{\mathrm{b})}$ & 3.06 & 2.75 & $\mathrm{hr}-1$ \\
\hline $\mathrm{T}_{1 / 2} \mathrm{~K}_{10}$ & 0.41 & 0.32 & $\mathrm{hr}$ \\
\hline $\mathrm{T}_{1 / 2} \alpha$ & 0.29 & 0.32 & $\mathrm{hr}$ \\
\hline $\mathrm{T}_{1 / 2} \beta$ & 1.33 & 1.08 & $\mathrm{hr}$ \\
\hline $\mathrm{T}_{1 / 2} \gamma$ & 8.36 & 4.94 & $\mathrm{hr}$ \\
\hline $\mathrm{AUC}_{0 \text {-inf }}{ }^{\mathrm{c})}$ & 313.97 & 287.61 & $n \mathrm{~g} \cdot \mathrm{hr} / \mathrm{ml}$ \\
\hline $\mathrm{Cl}_{\text {total }}$ d) & 1.89 & 0.95 & $l / \mathrm{hr} \cdot \mathrm{kg}$ \\
\hline AUMC ${ }^{\mathrm{e})}$ & 637.3 & 419.31 & $n \mathrm{~g} \cdot \mathrm{hr} 2 / \mathrm{ml}$ \\
\hline $\mathrm{MRT}^{\mathrm{f})}$ & 2.63 & 1.78 & $\mathrm{hr}$ \\
\hline $\mathrm{Vss}^{\mathrm{g})}$ & 5.64 & 3.79 & $l / \mathrm{kg}$ \\
\hline
\end{tabular}

Three-compartment open model, $C(t)=A e-\alpha t+B e-\beta t+C e-\gamma t ; \quad$ a) Cmax, maximum plasma concentration; b) $\mathrm{K}_{10}$, elimination rate; c) AUC, area under the concentration-time curve; d) $\mathrm{Cl}$, total body clearance; e) AUMC, area under the first moment curve; f) MRT, mean residence time; g) Vdss, volume of distribution at steady state.

\section{REFERENCES}

1. Beani, L., Bianchi, C. and Crema, C. 1970. Effect of metoclopramide on isolated guinea-pig colon, (1) Peripheral sensitization to acetylcholine. Eur. J. Pharmacol. 12: 320-331. [Medline] [CrossRef]

2. Bateman, D. N., Kahn, C. and Davies, D. S. 1979. Concentration effect studies with oral metoclopramide. Br. J. Clin. Pharmacol. 
8: 179-182. [Medline] [CrossRef]

3. Bateman, D. N., Kahn, C., Mashiter, K. and Davies, D. S. 1978. Pharmacokinetic and concentration-effect studies with intravenous metoclopramide. Br. J. Clin. Pharmacol. 6: 401-407. [Medline] [CrossRef]

4. Bryson, S. M., McGovern, E. M., Kelman, A. W., White, K., Addis, G. J. and Whiting, B. 1985. The pharmacokinetics of high dose metoclopramide in patients with neoplastic disease. $\mathrm{Br} . J$. Clin. Pharmacol. 19: 757-766. [Medline] [CrossRef]

5. Clark, D. and White, F. J. 1987. D1 dopamine receptor-the search for a function: a critical evaluation of the D1/D2 dopamine receptor classification and its functional implications. Synapse 1: 347-388. [Medline] [CrossRef]

6. Dowling, P. M. 1995. Prokinetic drugs: metoclopramide and cisapride. Can. Vet. J. 36: 115-116. [Medline]

7. Elliott, P., Seemungal, B. M. and Wallis, D. I. 1990. Antagonism of the effects of 5-hydroxytryptamine on the rabbit isolated vagus nerve by BRL 43694 and metoclopramide. Naunyn Schmiedebergs Arch. Pharmacol. 341: 503-509. [Medline]

8. Huhn, J. C., Koritz, G. D., Nelson, D. R. and Brown, S. A. 1992. Pharmacokinetics of metoclopramide in goats. J. Vet. Pharmacol. Ther. 15: 19-27. [Medline] [CrossRef]

9. Jones, R. D. and Bowen, J. M. 1991. Determination of metoclopramide in the serum and urine of cattle. Vet. Hum. Toxicol. 33: 551-553. [Medline]

10. Jones, R. D., Blanton, C. D. and Bowen, K. M. 1993. Identification of metoclopramide in the urine of cattle by gas chromatography-mass spectrometry and high-performance liquid chromatography-photodiode array detection. Vet. Res. Commun. 17: 387-396. [Medline] [CrossRef]

11. Jones, R. D., Mizinga, K. M., Thompson, F. N., Stuedemann, J. A. and Bowen, J. M. 1994. Bioavailability and pharmacokinetics of metoclopramide in cattle. J. Vet. Pharmacol. Ther. 17: 141-147. [Medline] [CrossRef]

12. Lee, H. W., Ji, H. Y., Kim, H. Y., Park, E. S., Lee, K. C. and Lee, H. S. 2009. Determination of metoclopramide in human plasma using hydrophilic interaction chromatography with tandem mass spectrometry. J. Chromatogr. B Analyt. Technol. Biomed. Life Sci. 877: 1716-1720. [Medline] [CrossRef]

13. Leucuța, A., Vlase, L., Farcău, D. and Nanulescu, M. 2004. Pharmacokinetic interaction study between ranitidine and metoclopramide. Rom. J. Gastroenterol. 13: 211-214. [Medline]

14. Magueur, E., Hagege, H., Attali, P., Singlas, E., Etienne, J. P. and Taburet, A. M. 1991. Pharmacokinetics of metoclopramide in patients with liver cirrhosis. Br. J. Clin. Pharmacol. 31: 185-187. [Medline] [CrossRef]

15. Riggs, K. W., Szeitz, A., Rurak, D. W., Mutlib, A. E., Abbott, F. S. and Axelson, J. E. 1994. Determination of metoclopramide and two metabolites using a sensitive and selective gas chromatographic-mass spectrometric assay. J. Chromatogr. B Biomed. Appl. 660: 315-325. [Medline] [CrossRef]

16. Yan, M., Li, H. D., Chen, B. M., Liu, X. L. and Zhu, T. G. 2010. Determination of metoclopramide in human plasma by LC-ESIMS and its application to bioequivalence studies. J. Chromatogr. B Analyt. Technol. Biomed. Life Sci. 878: 883-887. [Medline] [CrossRef] 